\title{
PENGARUH LUBANG PERFORASI DINDING CAISSON TERHADAP GAYA GELOMBANG
}

\author{
Kasmawati \\ Universitas Muhammadiyah Makassar, Indonesia \\ Email :kasma80508@rocketmail.com
}

\begin{abstract}
ABSTRAK
Sebagai struktur pantai yang dipengaruhi oleh faktor internal struktur dan kondisi eksternal yang mengikutinya, maka model Caisson diharapkan dapat mengurangi tinggi gelombang datang pada struktur, sehingga gaya yang bekerja pada struktur juga berkurang dengan semakin besarnya nilai porositas pada struktur. Tujuan dari penelitian ini adalah untuk mengetahui pengaruh lubang porositas dinding Caisson terhadap gaya gelombang pada struktur dan untuk mengetahui hubungan parameter lubang pori dengan besaran gaya gelombang. Penelitian dilakukan dengan menggunakan model dengan variasi diameter lubang dan variasi jarak antar lubang pada setiap model yang diteliti untuk melihat pengaruhnya terhadap besarnya gaya gelombang. Dari hasil penelitian menunjukkan bahwa besarnya gaya gelombang dipengaruhi oleh luasnya daerah terpaan gelombang dalam hal ini luas penampang model, selain itu tinggi gelombang datang juga sangat berpengaruh terhadap besarnya gaya gelombang. Semakin luas penampang model yang diterpa gelombang maka semakin besar gaya yang bekerja pada model, dalam hal ini bahwa semakin besar nilai porositas model, maka gaya yang bekerja akan semakin kecil. Model tanpa Porositas nilai gayanya 1,46 sedangkan model dengan porositas paling besar yaitu porositas $0,21 \mathrm{~m}^{2}$ nilai gayanya hanya 0.47. Hal ini terjadi karena semakin besar porositas maka disipasi gelombang datang akan semakin besar.
\end{abstract}

Kata Kunci : Defleksi, Gaya gelombang, Porositas

\begin{abstract}
As the structure of the coast affected by the structure of internal factors and external conditions are followed, then the model is expected to reduce the Caisson high wave came on the structure, so that the forces acting on the structure also decreases as the amount of porosity in the structure. The purpose of this study was to determine the effect of porosity holes Caisson wall against wave forces on the structure and to determine the relationship parameter pore holes with the forces of waves. The study was conducted using a model with a variation of hole diameters and variations of the distance between holes on each model being studied to see its effect on the force of the waves. The results showed that the magnitude of the wave force is influenced by the extent of inundation areas in this regard sectional area of the model, in addition to the coming wave height also affects the magnitude of the force of the waves. The more broad cross-section model buffeted by the waves, the greater the force exerted on a model in this regard, that the greater the value of porosity models, then the force will be smaller works. Models with 0 value style Porosity 1.46, while models with the greatest porosity is porosity value of $0.21 \mathrm{~m} 2$ style just 0:47. This happens because of the greater porosity of the dissipation of the incident wave will be even greater.
\end{abstract}

Keywords: Deflection, Wave Force, porosity

\section{PENDAHULUAN}

Pembebanan akibat gelombang laut pada struktur-struktur lepas pantai dipengaruhi oleh faktor-faktor internal struktur dan kondisi eksternal yang mengikutinya. Gelombang laut, angin, gempa bumi, pergerakan tanah, benturan dengan kapal, korosi, badai, pertumbuhan organik adalah faktor eksternal yang sangat acak di alam dan sulit untuk dimodelkan. Struktur-struktur yang dibebani oleh gelombang laut perlu dilakukan analisa dengan cermat, terutama pada saat terjadinya respons struktur 


\section{Jurnal Teknik Hidro}

\section{Vol. 11 No. 1, Februari 2018}

yang didominasi oleh interaksi antara struktur dengan fluida di sekelilingnya.

Interaksi struktur dengan fluida tersebut dimanifestasikan oleh munculnya massa tambahan (added mass) dalam dinamika responsnya.

Interaksi antara struktur dengan fluida dalam pembebanan gelombang dapat dirumuskan melalui persamaan Gaya Morison, yaitu dalam bentuk penjumlahan gaya inersia dan gaya seret.

Untuk menentukan suatu model struktur yang baru maka hal yang perlu diperhatikan adalah efektifitas dan keefisienan dari struktur tersebut, baik dari sisi pembuatan model maupun dari sisi biaya. Oleh karena itu, kami akan membuat suatu model struktur yaitu "Model Caisson" dengan memberikan beberapa variasi perforasi pada dinding Caisson tersebut.

Penelitian oleh Firmansyah dkk (2012), menyatakan bahwa pengaruh jarak kedalaman kantong pasir yang tercelup dalam mempengaruhi stabilitas, sehingga semakin dalam kantong pasir yang tercelup maka nilai kestabilitasanya akan semakin baik karena tinggi gelombang yang datang mengenai tumpukan kantong pasir akan sangat relatif lebih jauh akibat jarak freeboard. Sehingga untuk model dengan nilai d/H yang lebih kecil maka nilai stabilitas $(H / \Delta D)$ menjadi besar akibat jarak freeboard yang lebar.

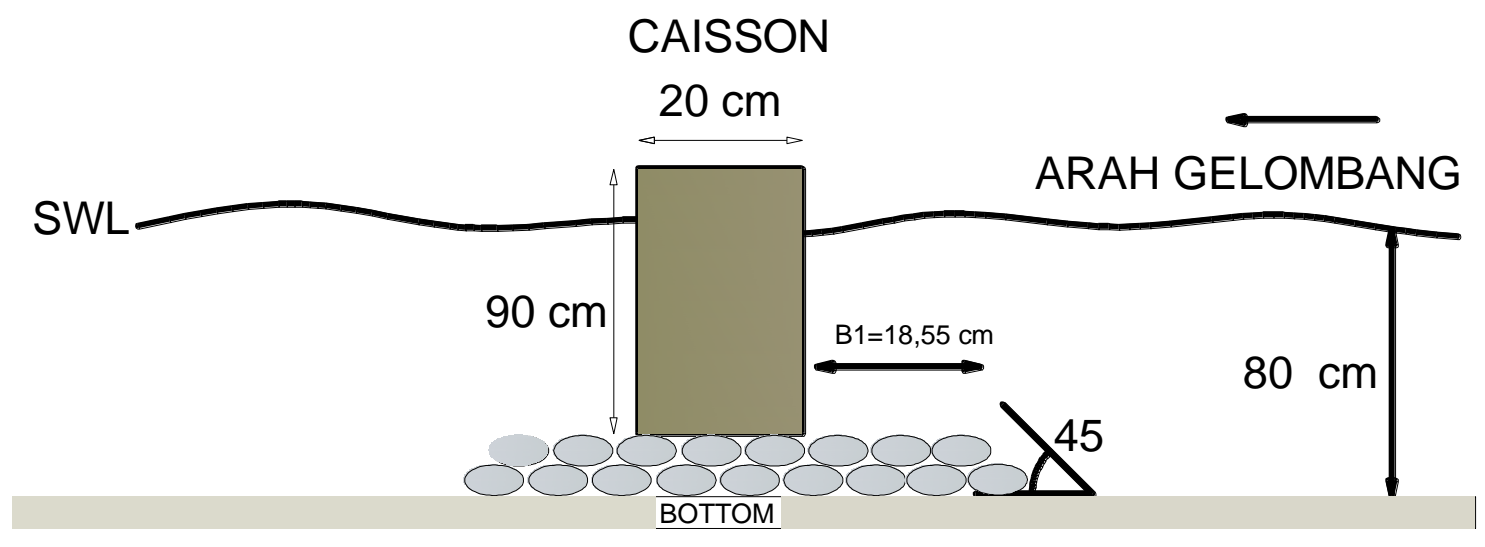

Gambar 1. Design pengujian model 1 konfigurasi pertama dengan sarat air di wave flume tampak samping (Firmansyah, dkk, 2012) 


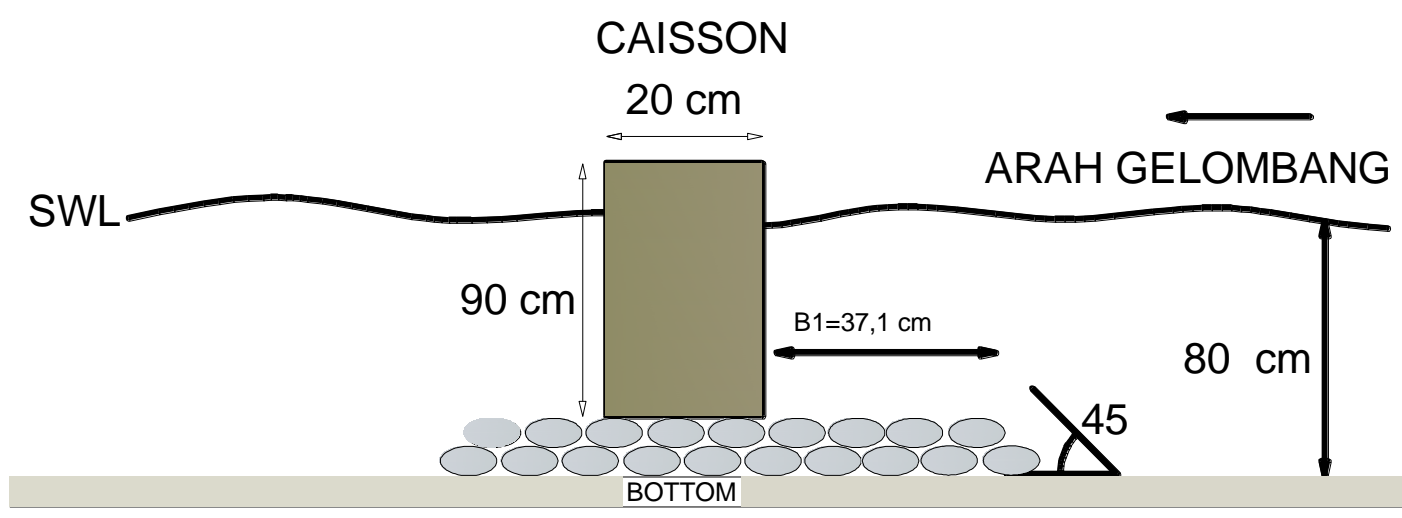

Gambar 2. Design pengujian model 1 konfigurasi kedua dengan sarat air di wave flume tampak samping (Firmansyah, dkk, 2012)

Rahman (2008), mengemukakan gelombang yang besar mengakibatkan bahwa nilai koefisien drag $\left(\mathrm{C}_{\mathrm{D}}\right)$ memiliki hubungan terhadap angka $R e$, semakin besar nilai $R e$ maka nilai $\mathrm{C}_{\mathrm{D}}$ akan semakin kecil. Selain itu, tinggi gelombang juga berpengaruh terhadap besarnya gaya gelombang. Hal ini terjadi karena tinggi kecepatan partikel air yang meningkat. Kedalaman air juga berpengaruh pada besarnya gaya gelombang. Makin besar kedalaman air maka gaya gelombang juga akan besar. Hal ini dikarenakan puncak model selalu berada di atas fluktuasi muka air.
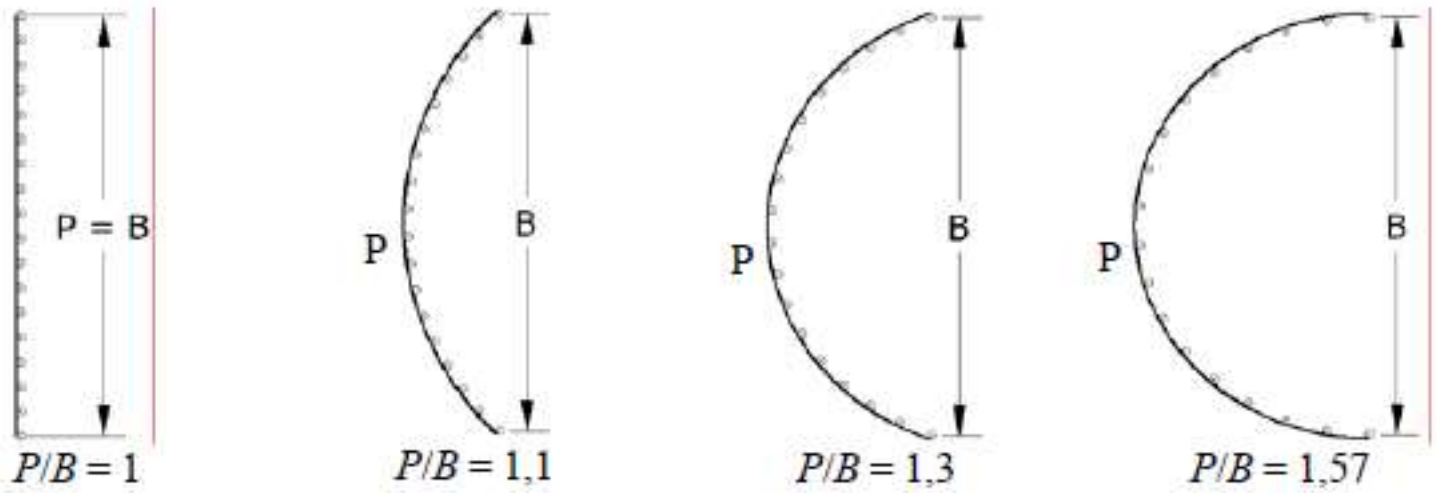

Gambar 3. Bentuk model APO (Rahman, 2008) 


\section{Jurnal Teknik Hidro}

\section{Vol. 11 No. 1, Februari 2018}

Menurut Mogridge \& Jamieson (1976), menyatakan bahwa pada penelitian gaya gelombang ada beberapa faktor yang berpengaruh, yaitu diantaranya panjang gelombang, periode gelombang dan ukuran model. Triatmadja dkk (2009), meneliti pengaruh porositas terhadap gaya gelombang tsunami yang menunjukkan adanya pengaruh porositas bangunan $(0 \%, 20 \%, 40 \%$, dan $60 \%)$ terhadap gaya gelombang tsunami. Makin besar porositas, maka penurunan besarnya gaya gelombang tsunami makin kecil.
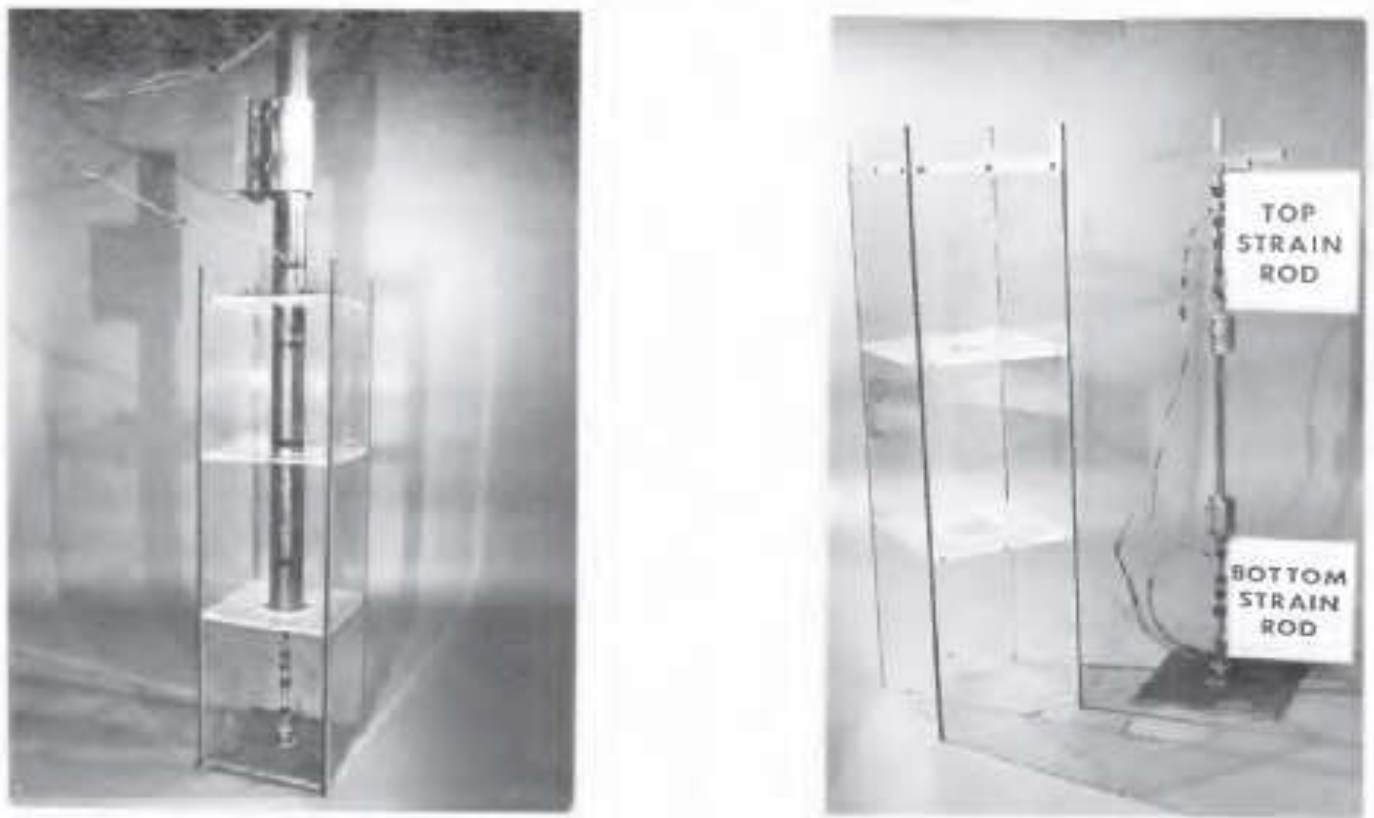

Gambar 4. Model Caisson, 6 Ft wave flume (Mogridge, G.R. dan Jamieson, 1976)
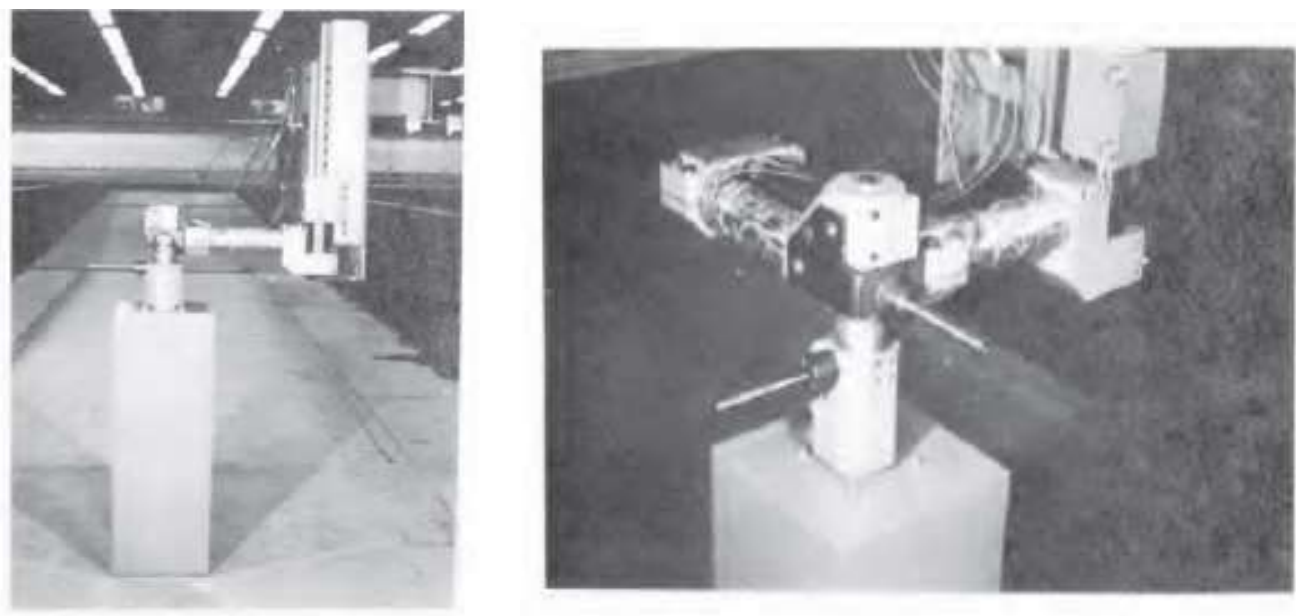

Gambar 5. Model Caisson, 12 Ft wave flume (Mogridge, G.R. dan Jamieson, 1976) 
Nurhasanah dkk (2010), meneliti gaya gelombang tsunami pada bangunan berpenghalang yang mendapatkan bahwa besarnya gaya gelombang dipengaruhi oleh bentuk bangunan. Lukkunaprasit dkk (2009), juga meneliti gaya gelombang pada bangunan berlubang $25 \%$ dan $50 \%$ yang menyatakan bahwa reduksi gaya akibat adanya lubang pada bangunan sebesar $15 \%$ 30\%. Fujima (2006), melakukan penelitian yang cukup komprehensif tentang gaya gelombang pada bangunan. Gelombang tsunami dimodelkan dengan flume yang panjangnya sekitar $11 \mathrm{~m}$. Walaupun panjang gelombang tsunami yang dihasilkan jauh dari kenyataan, gaya gelombang yang pertama mengenai bangunan cukup relevan dengan kondisi yang sebenarnya. Tujuan penelitian untuk mengetahui pengaruh dan hubungan parameter lubang pori terhadap besaran gaya gelombang.

$$
\text { Gelombang datang yang }
$$
mengenai/membentur satu rintangan akan dipantulkan sebagian atau seluruhnya.
Tinjauan refleksi gelombang penting di dalam perencanaan bangunan pantai, terutama pada bagian pelabuhan. Refleksi gelombang di dalam pelabuhan akan menyebabkan ketidaktenangan di dalam perairan, maka bangunan-bangunan yang ada di pelabuhan/pantai harus dapat menyerap/menghancurkan energy gelombang.

Susunan pancangan struktur tersebut berfungsi untuk merefleksikan gelombang. Alat ini dapat berfungsi dengan baik jika pancangan struktur dibuat serapat mungkin. Kekurangan dari jenis ini adalah diperlukan pekerjaan pemancangan yang banyak.

Besar kemampuan suatu bangunan memantulkan gelombang diberikan oleh koefisien refleksi $\mathrm{Hr}$ dan tinggi gelombang datang Hi:

$$
X=\frac{H_{r}}{H_{i}}
$$

Koefisien refleksi bangunan diestimasi berdasarkan tes model, seperi disajikan dalam tabel berikut: 


\section{Jurnal Teknik Hidro}

\section{Vol. 11 No. 1, Februari 2018}

Tabel 1. Koefisien refleksi

\begin{tabular}{lc}
\hline \multicolumn{1}{c}{ Tipe Bangunan } & $\mathrm{X}$ \\
\hline Dinding vertikal dengan puncak di atas air & $0,7-1,0$ \\
Dinding vertikal dengan puncak terendam & $0,5-0,7$ \\
Tumpukan batu sisi miring & $0,3-0,6$ \\
Tumpukan balok beton & $0,3-0,5$ \\
Bangunan vertikal dengan peredam energy (diberi lubang) & $0,05-0,2$ \\
& \\
\hline
\end{tabular}

(Sumber: Bambang Triatmodjo, Teknik Pantai)

Dinding vertical dan tak permiabel memantulkan sebagian gelombang. Pada bangunan seperti itu, koefisien refleksi adalah $X=1$, dan tinggi gelombang yang dipantulkan sama dengan tinggi gelombang datang. Gelombang di depan dinding vertical merupakan superposisi dari kedua gelombang dengan periode, tinggi dan angka gelombang yang sama tetapi berlawanan arah. Apabila Refleksi sempurna, $\mathrm{X}=1$ maka

$$
\eta=H_{i} \cos k x \cos \sigma t
$$

Gelombang yang menjalar dari laut dalam (deep water) menuju ke pantai akan mengalami perubahan bentuk karena adanya perubahan kedalaman laut. Apabila gelombang bergerak mendekati pantai, pergerakan gelombang di bagian bawah yang berbatasan dengan dasar laut akan melambat. Ini adalah akibat dari friksi/ gesekan antara air dan dasar pantai. Sementara itu, bagian atas gelombang di permukaan air akan terus melaju. Semakin menuju ke pantai, puncak gelombang akan semakin tajam dan lembahnya akan semakin datar. Fenomena ini yang menyebabkan gelombang tersebut kemudian pecah.

Gelombang terjadi karena hembusan angin di permukaan air. Daerah dimana gelombang dibentuk disebut daerah pembangkitan gelombang (wave generating area). Gelombang yang terjadi di daerah pembangkitan disebut 'sea' sedangkan gelombang yang terbentuk diluar daerah pembangkitan disebut 'swell'. Ketika gelombang menjalar, partikel air bergerak dalam suatu lingkaran vertikal kecil dan tetap 


\section{Jurnal Teknik Hidro}

\section{Vol. 11 No. 1, Februari 2018}

pada posisinya selagi bentuk dan energi gelombang berjalan maju. Partikel air di permukaan bergerak dalam suatu lingkaran besar dan membentuk puncak gelombang di puncak lingkaran dan lembah gelombang pada lintasan terendah. Di bawah permukaan, air bergerak dalam lingkaran-lingkaran yang makin kecil sampai pada kedalaman lebih besar dari setengah panjang gelombang.

Secara skematik dimensi mengenai karakteristik gelombang dapat dilihat pada gambar 6 berikut :

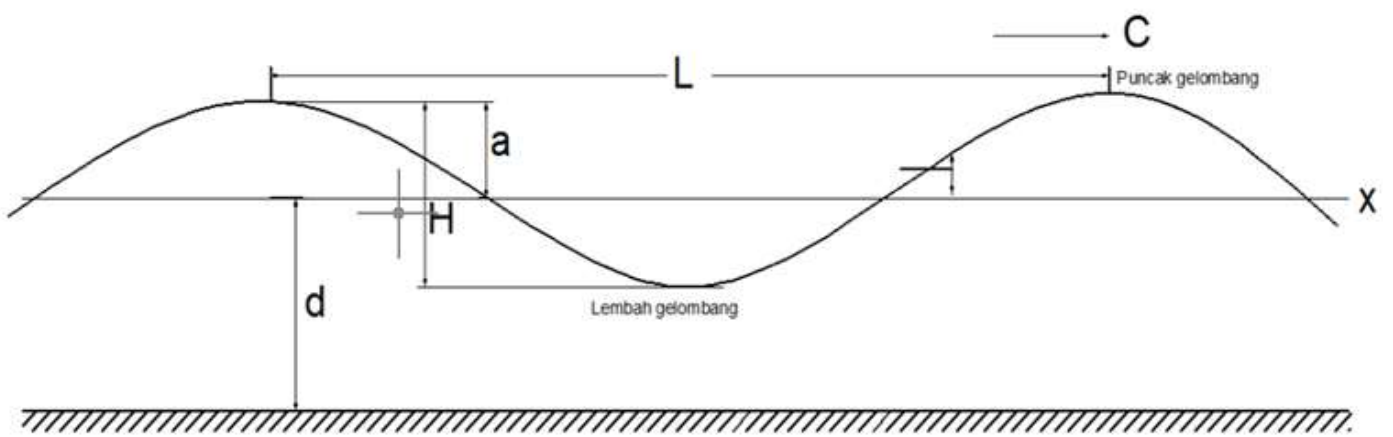

Gambar 6. Karakteristik gelombang

\section{BAHAN DAN METODE}

\section{Desain Penelitian}

Kegiatan penelitian dilaksanakan di Laboratorium Hidrolika Teknik Sipil Gowa Fakultas Teknik Universitas Hasanuddin, dengan waktu penelitian selama kurang lebih 2 bulan. Penelitian gelombang ini dilakukan pada saluran gelombang (wave flume) yang berukuran panjang $15 \mathrm{~m}$ dan lebar $30 \mathrm{~cm}$. Kedalaman efektif saluran adalah $45 \mathrm{~cm}$. Mesin pembangkit gelombang (wave generator) adalah tipe flap. Gerakan gelombang diciptakan oleh wave making flap, bagian bawah flap merupakan engsel dan bagian atas flap dihubungkan dengan piringan penggerak menggunakan stroke. Gerakan flap adalah gerakan rotasi yang dikontrol melalui gerak putar piringan penggerak. Gerakan/kepakan bolak-balik flap inilah yang membangkitkan gelombang. Sketsa model penelitian ini dapat dilihat pada gambar 1.

Karakteristik gelombang yang bisa dibangkitkan oleh wave generator pada saluran gelombang adalah berkisar $2-12 \mathrm{~cm}$ dengan periode berkisar 0.6-6 detik. Sedangkan jenis gelombang yang dibangkitkan adalah gelombang reguler. 


\section{Jurnal Teknik Hidro}

\section{Vol. 11 No. 1, Februari 2018}

Tinggi gelombang dapat divariasikan dengan melakukan penyetelan pada stroke atau piringan dalam beberapa variasi untuk merubah besaran simpangan flap. Demikian juga periode gelombang ( $T$ ) dapat divariasikan dengan menyetel kecepatan putar piringan.

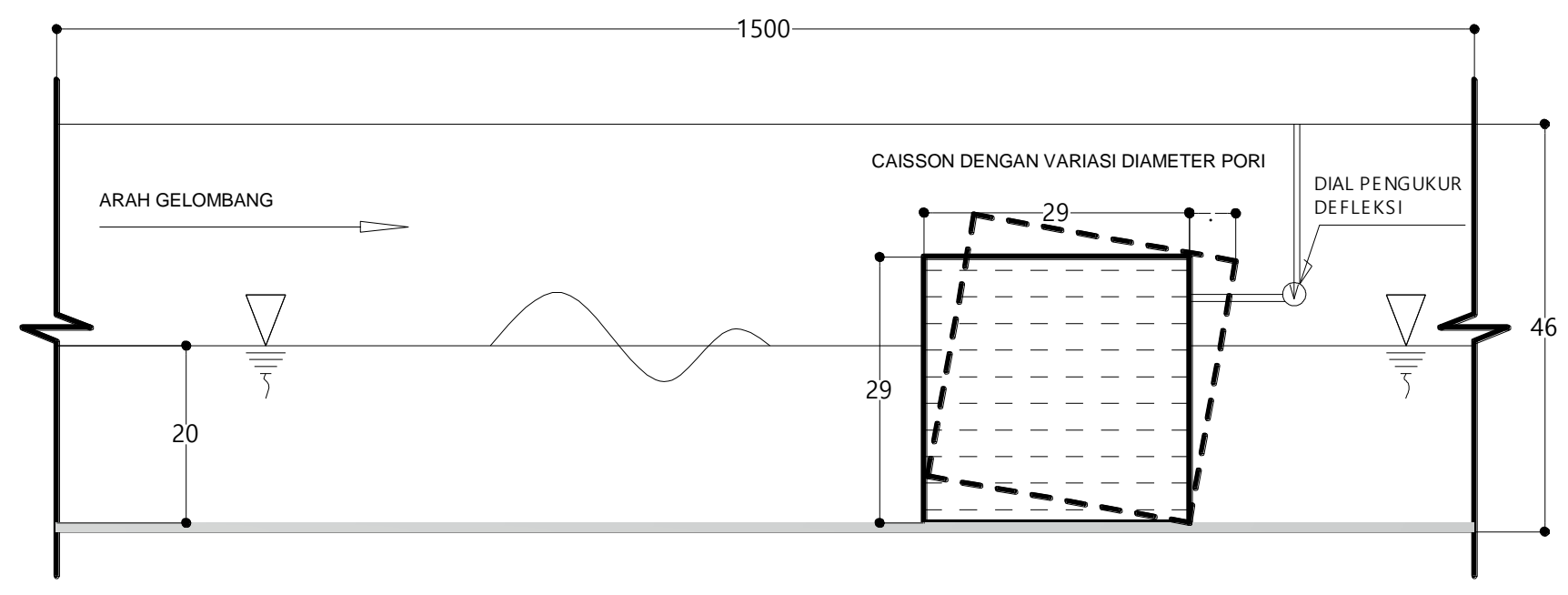

Gambar 7. Sketsa Model Penelitian

\section{Variabel yang Diteliti}

Sesuai dengan tujuan penelitian yang telah dikemukakan pada bab sebelumnya, maka variabel terikat yang diteliti adalah tekanan gelombang $(\mathrm{P})$, gaya gelombang $(\mathrm{F})$, sedangkan variabel bebas dalam penelitian ini adalah periode gelombang ( $T$ ), tinggi gelombang $(\mathrm{Hi})$, diameter lubang, jarak antar lubang dan Luas penampang struktur (A).

\section{Pengumpulan Data}

Dalam melakukan penelitian ini langkah pertama yang dilakukan adalah studi pendahuluan yang selanjutnya diteruskan dengan kajian pustaka dari berbagai teori dasar, kemudian dilakukan pengambilan data dengan melakukan simulasi penelitian di laboratorium. Data yang diperoleh di laboratorium mencakup data kenaikan gelombang maksimum dan minimum pada sembilan titik di depan model guna mendapatkan data tinggi gelombang datang, selain itu diperoleh juga data panjang gelombang yang diperoleh dengan pengamatan langsung di laboratorium, dan data periode gelombang yang diperoleh dengan mengukur waktu yang dibutuhkan 


\section{Jurnal Teknik Hidro}

\section{Vol. 11 No. 1, Februari 2018}

untuk mencapai satu gelombang, serta data tinggi air dalam reservoir dalam fungsi waktu.

\section{Metode Analisis Data}

Dalam menganalisa hubungan antara gaya gelombang dengan parameter parameter digunakan analisa dengan mengkonversi hasil penelitian yang diambil dengan menggunakan beban dan menggunakan gelombang. Selain itu, dengan menganalisa gaya dengan cara teoritis dengan menggunakan persamaan (Goda, 1985).

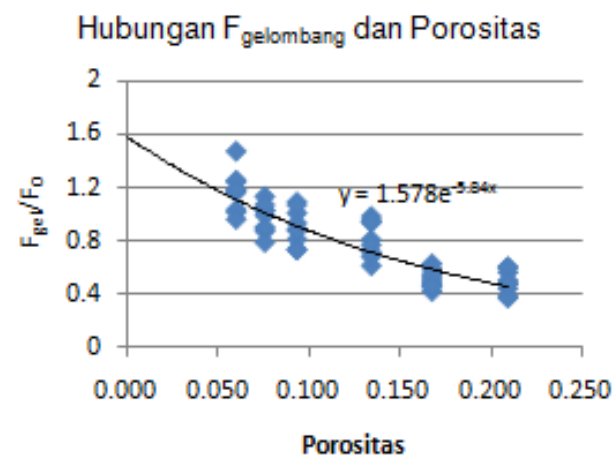

Gambar 8. Gaya gelombang (Hasil Analisa)

Model dengan nilai porositas 0 beratnya paling besar dan nilai porositas paling besar beratnya sangat kecil. Dalam hal ini, nilai porositas dan berat model berbanding terbalik. Hal ini disebabkan karena berkurangnya material pada setiap

\section{HASIL PENELITIAN}

Besar kecilnya gaya yang bekerja pada struktur berbanding lurus dengan besarnya defleksi yang terjadi. Dengan kata lain semakin besar beban yang dialami struktur maka defleksi yang terjadi pun semakin kecil. Dalam kajian ini ada beberapa variabel yang mempengaruhi besar kecilnya gaya yang bekerja dan besarnya defleksi. Dengan menghitung gaya apung, berat masing-masing model dan pengaruhnya terhadap porositas dan defleksi yang terjadi pada masing-masing model. Grafik hasil analisa dapat dilihat pada gambar 8 .

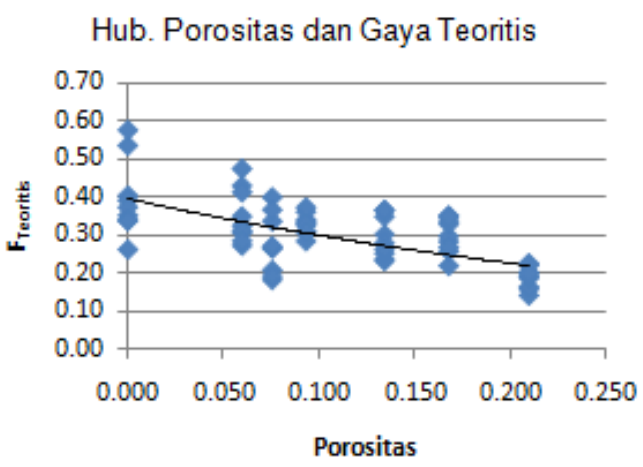

model sehingga luas penampang model juga berkurang. Oleh karena itu, berat model berkurang seiring bertambahnya nilai porositas. Grafik hasil analisa dapat dilihat pada gambar 9 . 

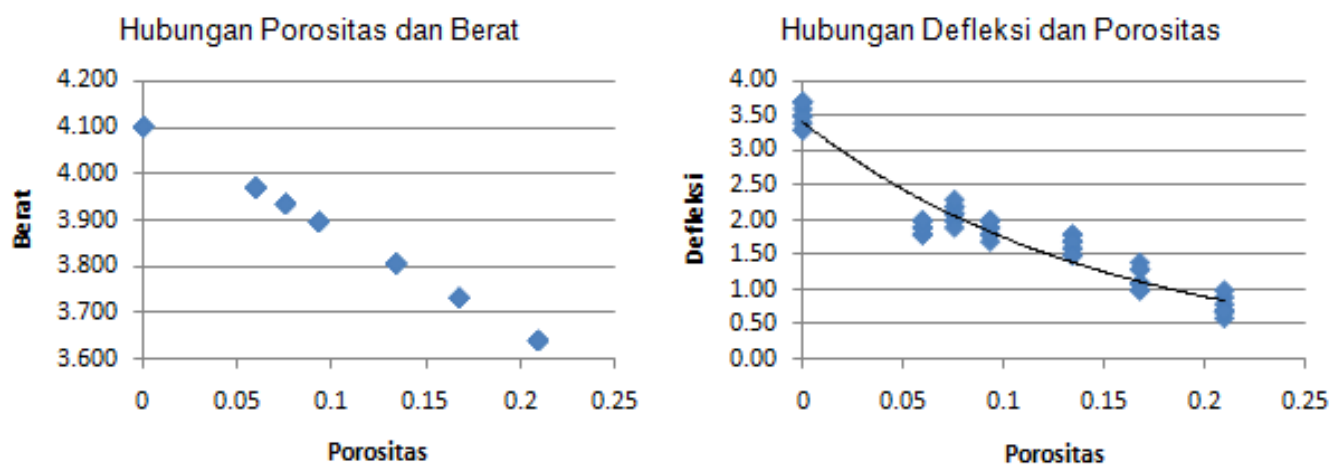

Gambar 9. Defleksi Struktur (Hasil Analisa)

Hubungan perbandingan momen tertahan dengan momen guling dengan porositas berbanding lurus. Semakin besar nilai porositas maka nilai juga besar begitu pula sebaliknya, jika nilai porositas kecil maka nilai juga besar. Secara teoritis
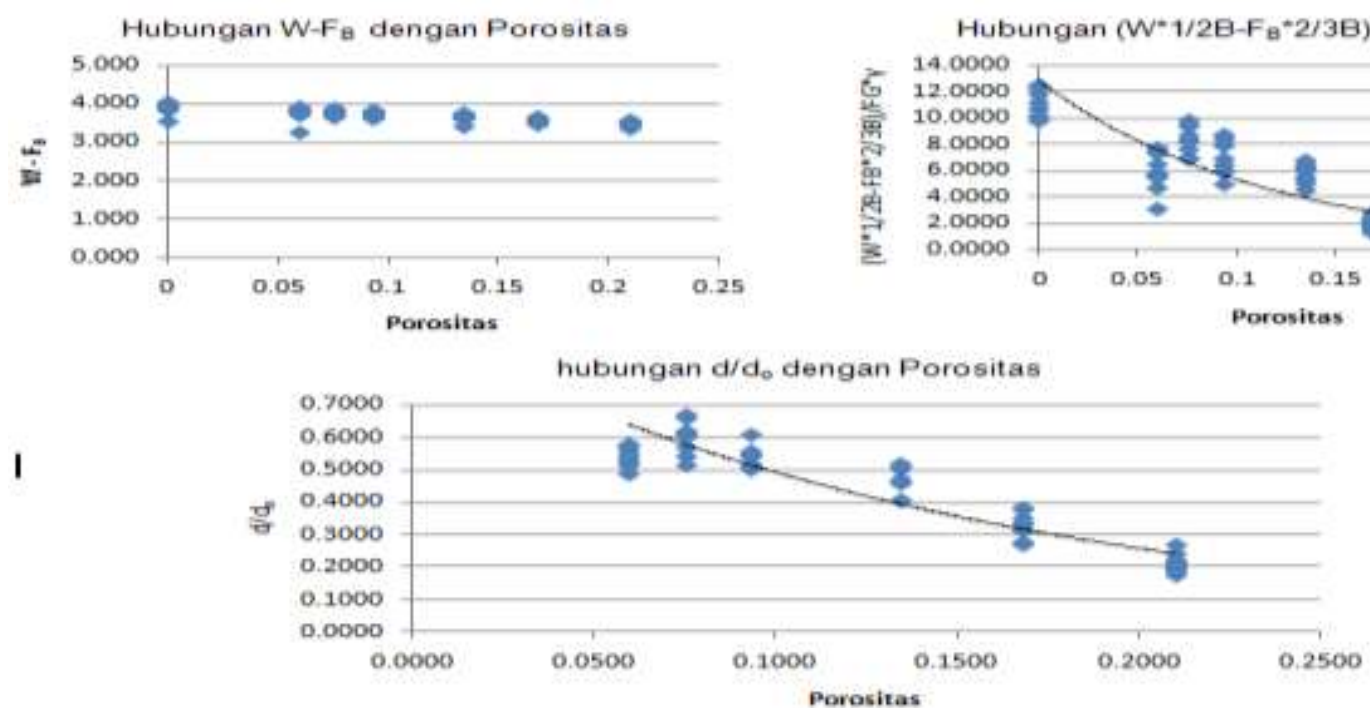

Gambar 10. Defleksi Struktur (Hasil Analisa)

PEMBAHASAN

Penelitian ini menunjukkan adanya kecenderungan nilai gaya gelombang $\left(F_{\text {Gel. }}\right)$ menjelaskan bahwa jika nilai momen tertahan besar daripada nilai momen guling, maka struktur aman/tidak bergerak, dalam kata lain bahwa nilai defleksi sangat kecil. Grafik hasil analisa dapat dilihat pada gambar 10.

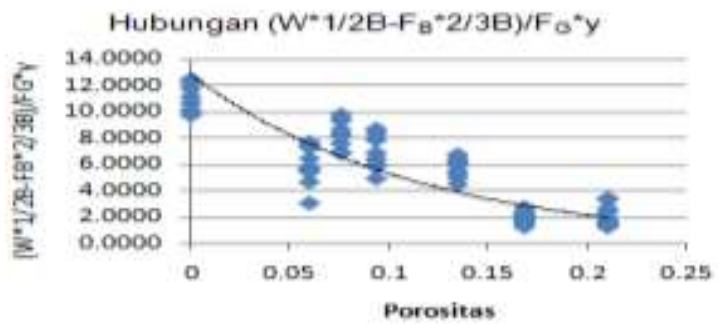

Porositas

semakin turun dengan semakin meningkatnya nilai porositas pada struktur, hal ini juga dibuktikan dari hasil kajian 
Fatnanta dkk (2012), yang mendapatkan bahwa gaya gelombang dipengaruhi oleh besarnya perubahan luas penampang yang diterpa gelombang. Hal ini disebabkan karena pada struktur dengan porositas yang lebih besar, gaya gelombang datang berkurang ketika gelombang sampai pada struktur pantai karena dengan tingginya nilai porositas yang terdapat pada dinding struktur menimbulkan disipasi yang besar pula sehingga gaya gelombang yang dipantulkan lebih kecil, untuk hal ini juga pernah diteliti oleh Lukkunaprasit dkk (2009), yang menyatakan bahwa reduksi gaya akibat adanya lubang pada bangunan sebesar $15 \%$ $30 \%$.

Selain menggunakan perbandingan gaya beban dan gaya gelombang, gaya dapat dihitung dengan cara teoritis. Nilai gaya yang bekerja pada struktur berbanding terbalik dengan nilai porositas. Semakin besar nilai porositas maka gaya akan semakin kecil. Secara teoritis, nilai gaya yang besar tetap pada model yang tidak memiliki porositas $($ porositas $=0 \mathrm{~cm})$. Hal ini diakibatkan karena secara teoritis gaya gelombang dihitung dengan menggunakan data tinggi gelombang, sehingga apabila porositas besar maka gelombang datang lebih kecil, mengibatkan hasil perhitungan gaya gelombang juga akan kecil. Dan secara teoritis dijelaskan bahwa salah satu parameter yang berpengaruh terhadap besarnya gaya gelombang adalah tinggi gelombang datang $\left(H_{i}\right)$ dan luasnya daerah terpaan gelombang (Triatmojo, 1999). Hubungan selisih berat model dengan gaya apung (Buoyancy Force) dengan porositas cenderung sama. Yaitu nilai $w-F_{B}$ (momen guling) berbanding terbalik dengan nilai porositas. Nilai porositas yang besar nilai momen guling $\left(w-F_{B}\right)$ kecil dan begitu sebaliknya, jika nilai porositas kecil maka nilai momen guling $\left(w-F_{B}\right)$ besar. Hal ini disebabkan karena adanya faktor berat pada model. Meskipun ada pengurangan pada gaya tetapi hal ini tidak terlalu berpengaruh karena gaya angkat (Buoyancy Force) yang ditimbulkan sangat kecil.

Hubungan perbandingan defleksi antara model yang memiliki porositas dengan model tanpa porositas terhadap nilai porositas adalah berbanding terbalik. Jika nilai porositas besar maka nilai $\frac{d}{d_{0}}$ akan kecil. Begitu juga sebaliknya, jika nilai porositas kecil maka nilai $\frac{d}{d_{0}}$ akan besar. Hal ini pernah dikaji oleh Akhwady dkk (2012), yang menyatakan bahwa kestabilan struktur dipengaruhi oleh luasnya gesekan permukaan terhadap gaya gelombang. 
Jurnal Teknik Hidro

Vol. 11 No. 1, Februari 2018

\section{KESIMPULAN DAN SARAN}

Dengan adanya pori (perforasi) pada dinding Caisson sangat berpengaruh terhadap gaya gelombang yang terjadi di mana terjadi pengurangan gaya gelombang seiring bertambahnya porositas pada struktur. Selain karena tingginya gelombang yang terdisipasi, juga disebabkan karena berkurangnya luas penampang pada model. Parameter struktur yang sangat berpengaruh terhadap gaya gelombang yaitu berat model, tinggi gelombang datang. Saran pada penelitian ini adalah penelitian ini menggunakan pencatatan tinggi gelombang manual dengan pengamatan visual, untuk mendapatkan pencatatan yang lebih baik disarankan penelitian selanjutnya menggunakan pencatat gelombang otomatis. Pencatat otomatis dapat menghasilkan data deret gelombang selama percobaan, sehingga efek refleksi dapat diketahui lebih jelas dibanding pengamatan manual. Diharapkan untuk penelitian selanjutnya untuk dapat mengkaji tentang pengaruh material pada struktur/model.

\section{DAFTAR PUSTAKA}

Akhwady R. dkk. (2012). Pengaruh Beda Porositas Terumbu Buatan Tipe Silinder Berongga (Bottle Reef TM) Sebagai Submerged Breakwater Terhadap Kinerja Peredaman Gelombang. Jurnal Ilmu Kelautan. Juni 2012. Vol 17.
Fatnanta F. dkk. (2011). Perilaku Deformasi Pemecah Gelombang Kantong Pasir Tipe Tenggelam. Jurnal Teknik Sipil. Vol 18. No. 2.

Firmansyah S. G. dkk. (2012). Stabilitas Pandasi pada Vertical Breakwater dengan Variasi Lebar dan Konfigurasi Kantong Pasir. Jurnal Teknik Pomits. Vol. 1, No. 1.

Fujima K. (2006). Measurement of Wave Force Acting on Building. National Defense Academy of Japan, Japan

Goda Y. (1985) Random Seas and Design of Maritime Structure. Advance Series on Ocean Engineering-Volume 15. University of Tokyo Press, Tokyo, Japan

Lukkunaprasit P. (2009). Wave Force on Buildings. The International Jounal of The Tsunami Society, Science of Tsunami Hazards

Mogridge G. R. \& Jamienson W. W. (1976). Wave Force on Square Caissons. Coastal Engineering Chapter 133.

Nurhasanah A. dkk. (2010). Gaya Gelombang Tsunami pada Bangunan Berpenghalang. PIT HATHI XXVII, Surabaya, 29-1 Agustus.

Rahman S. (2008). Koefisien Seret Gaya Gelombang pada APO dengan Tambahan Gedhek. Media Teknik Sipil : 91.

Triatmadja R. dkk (2009). Pengaruh Porositas Terhadap Gaya Gelombang Tsunami. Pertemuan Ilmiah Tahunan HATHI XXVI, Banjarmasin, 23-25 Oktober.

Triatmodjo B. (1999) Teknik Pantai. Beta Offset, Yogyakarta. 